\title{
Characterization of grafted jute fiber using acrylate monomers pretreated with alkali
}

\author{
Md. Ibrahim H. Mondal ${ }^{1 *}$, Md. Mashiur Rahman Khan², Md. Mofakkharul Islam', Md. Saiful Islam \\ and M. A. Rabbi ${ }^{3}$
}

*Correspondence:

mihmondal@yahoo.com

${ }^{1}$ Polymer and Textile

Research Lab, Department

of Applied Chemistry

and Chemical Engineering,

Rajshahi University, Rajshahi,

Bangladesh

Full list of author information

is available at the end of the

article

\begin{abstract}
The reactivity of lingocellulosic jute fiber to sunlight (UV) and atmospheric gases and chemicals was reduced by grafting jute with acrylate monomers, such as ethyl acrylate (EA) and 2-hydroxy ethyl methacrylate (HEMA). The grafting reaction sufficiently blocked the reactive groups of jute and thus, physically- and chemically-bound cellulosic units and on the fiber surface. The grafting gave additional strength, higher thermal stability and improved surface smoothness. Though the modified fibers showed better color fastness properties in sunlight, the dyeability of the modified fibers somewhat decreased. Grafting reaction and other characteristics of modified fibers were investigated with FT-IR, tensile tester, thermogravimeric analyser, and grey scale respectively. The change of surface morphology of the jute fiber on modification was also observed with a scanning electron microscopy. Modification of bleached jute and alkali-activated bleached jute with HEMA gave higher graft yield (26.6, 29.4\%) than that of EA modification (22.5, $24.7 \%)$. Due to the different chemical features, HEMAmodified fiber exhibited better chemical, thermal and physical properties.
\end{abstract}

Keywords: Grafting, Jute fiber, Acrylate monomer, Modification, Mechanical properties

\section{Introduction}

Jute is a natural, biodegradable, low-cost, multicellular, lignocellulosic fiber, produced in large quantities every year in South and Southeast Asia, especially in Bangladesh and neighboring India. Jute plants contain three main categories of chemical compounds: cellulose (58-63\%), hemicellulose (20-24\%) and lignin (12-15\%), and some other small quantities fats, pectin, aqueous extract, etc. (Chattopadhyay 1998; Tanmoy et al. 2014). This natural fiber has some inherent advantages for its renewable nature, biodegradability, high dry strength, moderate moisture regain, easy dyeability, and good thermal and sound insulation properties.

Recently, due to the improvement of people's living standards and need for environmental protection, the demand for natural, biodegradable and eco-friendly jute fiber has been rising day-by-day. In our daily life, it can serve many purposes, such as in the manufacture of sackings, hessians, carpet backing and the like.

However, jute has certain unfavorable properties. It is coarse, stiff and not extensible. It has low wet strength. It has a harsh feel. It is not very adaptable. It shrinks significantly

(c) 2016 Mondal et al. This article is distributed under the terms of the Creative Commons Attribution 4.0 International License (http://creativecommons.org/licenses/by/4.0/), which permits unrestricted use, distribution, and reproduction in any medium, provided you give appropriate credit to the original author(s) and the source, provide a link to the Creative Commons license, and indicate if changes were made. 
in washing. It has poor abrasion resistance. It tends to go yellow in light. It is also susceptible to microbial attack. These negative qualities have limited the demand for jute.

Therefore, to minimize their undesirable aspects and to enhance their effectiveness for intensified textile use, graft copolymerization of vinyl monomers onto jute fibers has been attempted during the recent years. This grafting has been done using chemical (Mondal et al. 2007; Mondal et al. 2004, 2006; Mondal 2003; Mondal and Haque 2007), photochemical (Ghosh and Paul 1983) and radiation-induced (Khan et al. 2010, 2015; Zaman et al. 2012) methods. In these attempts, the grafted fiber has shown improved thermal, tensile and color fastness properties.

Other work has been done on graft copolymerization of jute fiber with nitrile (Mondal et al. 2007, 2004; Mondal 2003), acrylate (Mondal and Haque 2007; Mondal et al. 2006, 2013), acrylic and amide monomer (Mondal et al. 2002) monomers. The purpose was to develop the grafting process and improve the resultant physical properties of the modified products. Scientists are now trying to create suitable coupling of the different chemical features on the jute reactive sites. This coupling will obtain smooth surface morphology with expected improvements in chemical, thermal and physical properties.

In this study, graft copolymerization of ethyl acrylate (EA) and 2-hydroxy-ethyl methacrylate (HEMA) was performed on alkali-activated jute fiber. Due to the very similar chemical features of EA and HEMA, both the monomers proceed with radical polymerization during grafting. However, the extra functional group $(\mathrm{OH})$ of HEMA would give some extent of cross-linking between two grafted HEMA on the jute surface, or two cellulosic units, along the fiber length. The grafting, through radical polymerization, for both the monomers, similarly improves the surface smoothness, chemical, thermal and physical properties. However, the additional cross-linking reaction of $\mathrm{OH}$ groups may demonstrate even better performance of HEMA-modified fiber.

\section{Method}

Materials

Raw jute fiber (Corchorus olitorius, Tossa variety) was collected from Rajshahi Jute Mills Ltd., Bangladesh. Reagent grade ethyl acrylate (EA, $\mathrm{CH}_{2}=\mathrm{CH}-\mathrm{COO}-\mathrm{CH}_{2} \mathrm{CH}_{3}$ ), 2-hydroxy-ethyl methacrylate ( $\mathrm{HEMA}, \mathrm{CH}_{2}=\mathrm{C}\left(\mathrm{CH}_{3}\right)-\mathrm{COO}-\mathrm{CH}_{2} \mathrm{CH}_{2} \mathrm{OH}$ ), potassium persulfate $\left(\mathrm{K}_{2} \mathrm{~S}_{2} \mathrm{O}_{8}, 99 \%\right)$, ferrous sulfate $\left(\mathrm{FeSO}_{4} \cdot 7 \mathrm{H}_{2} \mathrm{O}, 99.5 \%\right)$ and acetic acid were purchased from Merck (Germany), while sodium chlorite $\left(\mathrm{NaClO}_{2}, 80 \%\right)$ and sodium carbonate $\left(\mathrm{Na}_{2} \mathrm{CO}_{3}, 99.5 \%\right)$ were bought from $\mathrm{BDH}$ (England). The detergent was bought from Kohinoor Chemical Co. Ltd., Bangladesh.

\section{Preparation of the jute sample}

About $60 \mathrm{~cm}$ from the bottom of jute fiber was discarded and then $30 \mathrm{~cm}$ was taken for investigation. Dirt and waste materials were removed by treating the fiber with $6.5 \mathrm{~g}$ of detergent and $3.5 \mathrm{~g}$ of soda per liter at $70-75{ }^{\circ} \mathrm{C}$ for $30 \mathrm{~min}$ (Farouqui and Mondal 1989). This raw jute fiber was bleached with a $5 \mathrm{~g} / \mathrm{L}$ sodium chlorite solution of $\mathrm{pH} 4$ at $85-90{ }^{\circ} \mathrm{C}$, for $90 \mathrm{~min}$, in a fiber-liquor ratio of 1:50 (Mondal et al. 2007, 2004). After being washed well with distilled water, this fiber was rinsed with a $0.2 \%$ sodium metabisulfite solution for $15 \mathrm{~min}$. The bleached jute fiber was thoroughly washed with distilled water, dried at $105^{\circ} \mathrm{C}$, and then stored in a desiccator. 


\section{Alkali activation}

The bleached jute fiber was immersed in $5 \mathrm{~g} / \mathrm{L}$ aqueous solution of $\mathrm{NaOH}$ maintaining a fiber-liquor ratio of 1:50. Then the solution was heated, with occasional stirring, maintaining the temperature $60 \pm 1{ }^{\circ} \mathrm{C}$ for $30 \mathrm{~min}$. After being washed well with distilled water until neutral, the fiber was dried in open air. Alkali activation effectively reduces the lignin content in jute fiber.

\section{Purification of monomer}

EA and HEMA monomers were purified by washing twice with $5 \% \mathrm{NaOH}$ aqueous solution. Then they were washed several times with distilled water to remove the inhibitor. The remainder was then dried over anhydrous calcium chloride.

\section{Grafting}

The graft copolymerization of jute fiber was carried out in a $100 \mathrm{ml}$ stoppered Erlenmeyer flask. Polymerization was done with 40-110\% monomer, 1-6 \% potassium persulfate as initiator, and 1-6\% ferrous sulfate as catalyst, based on the weight of the fiber, at $40-80{ }^{\circ} \mathrm{C}$, for $30-150 \mathrm{~min}$, in the fiber-liquor ratio of 1:30. At the end of the desired reaction period, the fibers were washed with hot distilled water (Sikdar et al. 1995; Abou-Zeid et al. 1984; Samal et al. 1990). It was then extracted with acetone for $10 \mathrm{~h}$ in a soxhlet apparatus, to remove loosely adhering polymer, washed well and dried at $60{ }^{\circ} \mathrm{C}$ (Mondal et al. 2006). The weight of dried fiber, after and before modification, was taken. For precision, a blank experiment was done, which produced eventual weight reduction during modification. The graft yield was calculated according to the following formula (Sikdar et al. 1995):

Graft yield (\%) $=$ (weight of the grafted jute fiber - weight of the grafted jute fiber) $\times 100$ /weight of ungrafted jute fiber

$$
\begin{aligned}
\text { Grafting efficiency }(\%)= & \text { (weight of the grafted jute fiber } \\
& - \text { weight of ungrafted jutefiber }) \times 100 / \text { total monomer }
\end{aligned}
$$

\section{Dyeing}

Two direct dyes (Direct Blue 1 and Direct Orange 31) and two reactive dyes (Reactive Orange 14 and Brown 10) were used. The dye baths were prepared with $1 \%$ direct dye and $3 \%$ reactive dye on the basis of the fibers' weight, with the fiber-liquor ratio of 1:30. $25 \% \mathrm{NaCl}$ and $7 \% \mathrm{Al}_{2}\left(\mathrm{SO}_{4}\right)_{3}$ were also used as electrolytes in the direct and reactive dye baths, respectively. Dyeing was performed at $80{ }^{\circ} \mathrm{C}$ for $60 \mathrm{~min}$ with occasional stirring (Khan 2007). After dyeing, the fiber was washed well with distilled water and dried. The absorption of the dye was determined colorimetrically as follows:

$$
\text { Absorption of dye }(\%)=(\text { Do-De }) \times 100 / \text { Do }
$$

where, Do and De are the original and exhausted dye-bath concentrations, respectively.

\section{IR spectroscopy}

IR spectra of alkali-activated bleached and grafted jute fibers were recorded with a Shimadzu IR-8900 spectrophotometer (Shimadzu, Kyoto, Japan), using the KBr pellet technique. The 
dried fiber samples were crushed to a size that was finer than 20 meshes before pelleting with $\mathrm{KBr}$. The test KBr pellet contained about $1 \%$ powdered fiber (Misra 1987).

\section{Thermal behaviour}

Comparative thermal stabilities of alkali-activated bleached and modified jute fibers were studied by Thermogravimetric Analysis (TGA) with SEIKO-EXTAR TG/DTA-6300 (Seiko, Japan).

\section{Breaking strength of jute fiber}

Alkali-activated bleached and modified fibers were cut into equal pieces $25 \mathrm{~cm}$ in length. The length of each specimen between the jaws of the machine (Torsee's Scopper typeOS-100) was maintained at $10 \mathrm{~cm}(0.5 \mathrm{~g})$. One twist per $2 \mathrm{~cm}$ was given, along with the length of the fiber between the jaws, for measuring tensile strength. In each experiment, breaking strength for 10 specimens was taken and the mean of 10 readings was assumed to represent the tensile strength of the fiber (Mondal 2004). Breaking load was calculated as $\mathrm{kg} / \mathrm{yarn}$.

\section{Determination of moisture content}

The moisture content of the jute fibers was measured by a moisture analyzer (Model: R H 120-3, Kern, Germany). The heating was done at $105{ }^{\circ} \mathrm{C}$, with IR radiation, in the moisture analyzer. The temperature range of the analyzer was $0-250^{\circ} \mathrm{C}$.

\section{Sunlight exposure}

The jute sample was exposed on a flat board, under sunlight, without any protection from weather except from rain. At the same time, and in the same place, bleached and grafted jute fibers were directly exposed under the sun for $6 \mathrm{~h}$ each day in the month of May-July (Summer season). This was continued for 250 h (Sayeed 1987).

\section{Results and discussion}

\section{Chemical modification of bleached and alkali-activated bleached jute fibers}

Bleached and alkali-activated bleached jute fibers were chemically modified with ethyl acetate and 2-hydroxy ethyl methacrylate monomers at the varying monomer, initiator and catalyst concentrations. It was found that maximum graft yield depended on the type of monomer, catalyst and initiator concentrations, time and temperature. Optimum condition for maximum graft yield for EA and HEMA are listed in Table 1. Under optimized conditions, the maximum graft yields of EA and HEMA were 22.5, $26.6 \%$ for bleached and 24.7, 29.4\% for alkali-activated bleached jute respectively. So, the alkali activation prior to modification increased the grafting yield.

As the alkali treatment removed the lignin from the jute, the relative reactive surface of jute became available to be grafted with the monomers.

Figure 1 shows the graft yield of EA and HEMA onto jute fiber at optimum polymerization condition. The maximum graft yields for EA and HEMA were 24.7 and $29.4 \%$ at $60{ }^{\circ} \mathrm{C}$, respectively. At this temperature, both the initiator $\left(\mathrm{K}_{2} \mathrm{~S}_{2} \mathrm{O}_{8}\right)$ and the catalyst $\left(\mathrm{FeSO}_{4}\right)$ showed maximum efficiency to generate activated monomers and cellulose macroradicals in jute, which combined among themselves to give highest grafting. 
Table 1 Effective optimum conditions of grafting of EA and HEMA onto bleached and activated bleached jute fiber

\begin{tabular}{llllllll}
\hline Fiber type & Monomer & $\begin{array}{l}\text { Monomer } \\
\text { conc. (\%) }\end{array}$ & $\begin{array}{l}\text { Initiator } \\
\text { conc. (\%) }\end{array}$ & $\begin{array}{l}\text { Catalyst } \\
\text { conc. (\%) }\end{array}$ & $\begin{array}{l}\text { Reaction } \\
\text { time (min) }\end{array}$ & $\begin{array}{l}\text { Reaction } \\
\text { temp. }\left({ }^{\circ} \mathbf{C}\right)\end{array}$ & $\begin{array}{l}\text { Grafting } \\
\text { yield (\%) }\end{array}$ \\
\hline $\begin{array}{l}\text { Bleached jute EA } \\
\begin{array}{c}\text { Activated EA } \\
\text { bleached }\end{array}\end{array}$ & 80 & 4.5 & 5 & 90 & 60 & 22.5 \\
$\begin{array}{c}\text { jute } \\
\text { Bleached jute HEMA }\end{array}$ & 70 & 4.5 & 5 & 90 & 60 & 24.7 \\
$\begin{array}{c}\text { Activated } \\
\text { bleached }\end{array}$ & 70 & 4 & 4.5 & 90 & 60 & 26.6 \\
jute & & 4 & 4.5 & 90 & 60 & 29.4 \\
\hline
\end{tabular}

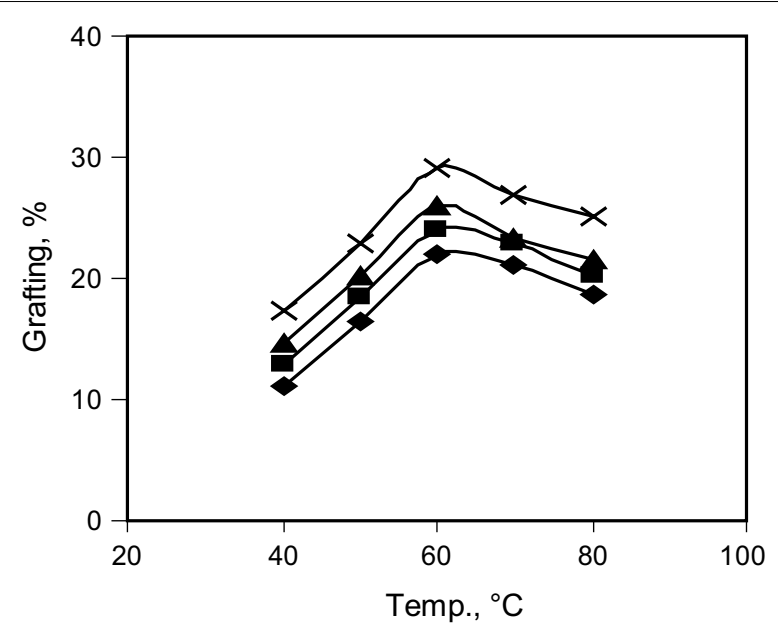

Fig. 1 Plots of polymerization temperature vs percent graft yield where $80 \%$ EA and $70 \%$ HEMA as monomer, $4.5 \% \mathrm{~K}_{2} \mathrm{~S}_{2} \mathrm{O}_{8}$ for EA and $4 \% \mathrm{~K}_{2} \mathrm{~S}_{2} \mathrm{O}_{8}$ for $\mathrm{HEMA}$ as initiator, $5 \% \mathrm{FeSO}_{4}$ for EA and $4.5 \% \mathrm{FeSO}_{4}$ for HEMA as catalyst, $90 \mathrm{~min}$ reaction time for both EA and HEMA (graft yield: filled diamond bleached modified with EA, filled square alkali-activated bleached modified with EA, filled triangle bleached modified with HEMA and Times alkali-activated bleached modified with HEMA

Again, the increase in temperature increased the rate of monomer diffusion (Sharma et al. 2003) into the jute matrix, where grafting was also initiated by the complex monomer. Decrease in graft yield beyond the optimum temperature might be the result of homopolymer formation over grafting. It is also possible that the growing grafted chains were prematurely terminated by the excess $\mathrm{Fe}(\mathrm{III})$ ions produced by the oxidation of the $\mathrm{Fe}(\mathrm{II})$ ions (Mondal et al. 2007, 2004). At temperatures over $60^{\circ} \mathrm{C}$, for both the EA and HEMA, the reaction became reversible. A ceiling temperature was established when the forward and backward reactions became equal. Consequently, at high temperatures, exceeding the optimum values, the graft yield started to decrease.

From Fig. 1, it appears that graft yield of HEMA is higher than that of EA. This was possibly caused by the following: (1) the molecular weight of HEMA is higher than that of EA, (2) the reactivity of the functional groups of HEMA is higher than that of EA, (3) varying chemical features of the functionality of the HEMA monomer make it more suitable to produce a higher graft yield. 
To understand cause (3) both EA $\left(\mathrm{CH}_{2}=\mathrm{CH}-\mathrm{COO}-\mathrm{CH}_{2} \mathrm{CH}_{3}\right)$ and HEMA $\left(\mathrm{CH}_{2}=\mathrm{CCH}_{3}-\mathrm{COO}-\mathrm{CH}_{2} \mathrm{CH}_{2} \mathrm{OH}\right)$ have one double bond each but there is an extra hydroxyl function group on HEMA. Due to the very similar chemical features of EA and HEMA, both the monomers proceeded with radical polymerization in grafting. However, the extra functional group $(\mathrm{OH})$ of HEMA might create some amount of polycondensation with the hydroxyl functional group of jute. The combined grafting mechanism might be the possible cause for the higher graft yield of HEMA compared to EA (Mondal 2007; Mondal and Hoque 2007).

The following sequence of grafting reactions would be expected to take place. They would ultimately lead to notable weight increase and changes in the chemical nature of jute fiber during the overall process. Since the grafting reactions were carried out in an aqueous medium, it is likely that the competitive reaction for grafting, (the homopolymerization reaction) would be initiated by radicals like $\mathrm{SO}_{4}{ }^{-}$and ${ }^{\circ} \mathrm{OH}$. These radicals are generated by the decomposition of $\mathrm{K}_{2} \mathrm{~S}_{2} \mathrm{O}_{8}$ (Mondal et al. 2002).

Following are pictorial representations of these reactions, for clarification:

Formation of macrojute and monomer radicals:

$$
\begin{aligned}
& \mathrm{J}_{\text {cell }}-\mathrm{H}+\mathrm{R}^{\cdot} \rightarrow \mathrm{J}_{\text {cell }}+\mathrm{RH} \\
& \mathrm{M}+\mathrm{R}^{\cdot} \rightarrow \mathrm{R}-\mathrm{M}
\end{aligned}
$$

Propagation

$$
\begin{aligned}
& \mathrm{J}_{\text {cell }}^{\cdot}+\mathrm{M} \rightarrow \mathrm{J}_{\text {cell }}-\mathrm{M}^{\cdot} \stackrel{(\mathrm{n}-1) \mathrm{M}}{\longrightarrow} \mathrm{J}_{\text {cell }}-\mathrm{O}-\mathrm{M} \cdot \mathrm{n} \\
& \mathrm{J}_{\text {cell }}-\mathrm{H}+\mathrm{M}-\mathrm{R} \rightarrow \mathrm{J}_{\text {cell }}-\mathrm{M}+\mathrm{RH} \stackrel{(\mathrm{n}-1) \mathrm{M}}{\longrightarrow} \mathrm{J}_{\text {cell }}-\mathrm{M} n
\end{aligned}
$$

Homopolymerization

$$
\mathrm{R}-\mathrm{M}+\mathrm{M} \rightarrow \mathrm{R}-\mathrm{M}-\mathrm{M} \stackrel{(\mathrm{n}-2) \mathrm{M}}{\longrightarrow} \mathrm{M} \cdot \mathrm{n}
$$

Termination

$$
\begin{aligned}
& \mathrm{R}-\mathrm{M} n+\mathrm{M}_{\mathrm{m}}-\mathrm{R} \rightarrow \mathrm{R}-\mathrm{M}_{\mathrm{n}}-\mathrm{M}_{\mathrm{m}}-\mathrm{R} \text { Formation of homopolymer } \\
& \mathrm{J}_{\text {cell }}^{\cdot}+\mathrm{M}_{\mathrm{n}}-\mathrm{R} \rightarrow \mathrm{J}_{\text {cell }}-\mathrm{M}_{\mathrm{n}}-\mathrm{R} \quad \text { Formation of Jute }-\mathrm{g}-\text { poly M copolymer }
\end{aligned}
$$

$\mathrm{J}_{\text {cell }}-\mathrm{M}_{\mathrm{n}}+\mathrm{M}_{\mathrm{m}}-\mathrm{J}_{\text {cell }} \rightarrow \mathrm{J}_{\text {cell }}-\mathrm{Mn}-\mathrm{Mm}-\mathrm{J}_{\text {cell }} \quad$ Crosslinking between jute celluloses via poly-M chain segments where, $\mathrm{R}^{*}$ is the primary radical $\left(\mathrm{SO}_{4}^{-}{ }^{\cdot}\right.$ or $\left.{ }^{\circ} \mathrm{OH}\right)$ produced by initiator, $\mathrm{J}_{\text {cell }}-\mathrm{H}$ is the jute cellulose or fiber, $\mathrm{M}$ is the monomer $\left(\mathrm{CH}_{2}=\mathrm{CH}-\mathrm{COO}-\mathrm{CH}_{2} \mathrm{CH}_{3}\right.$ or $\mathrm{CH}_{2}=\mathrm{C}\left(\mathrm{CH}_{3}\right)-\mathrm{COO}-\mathrm{CH}_{2} \mathrm{CH}-\mathrm{OH}$ ) and suffix ( $\mathrm{m}$ or $\mathrm{n}$ ) indicates the number of monomer.

\section{FT-IR studies for the conformation of grafting reaction}

The IR spectra of alkali-activated, bleached, EA-modified, and HEMA-modified jute fibers have been shown in Fig. 2. The spectra of the modified samples were more or less similar in nature to that of the alkali-activated bleached jute fiber, except for the peaks at 


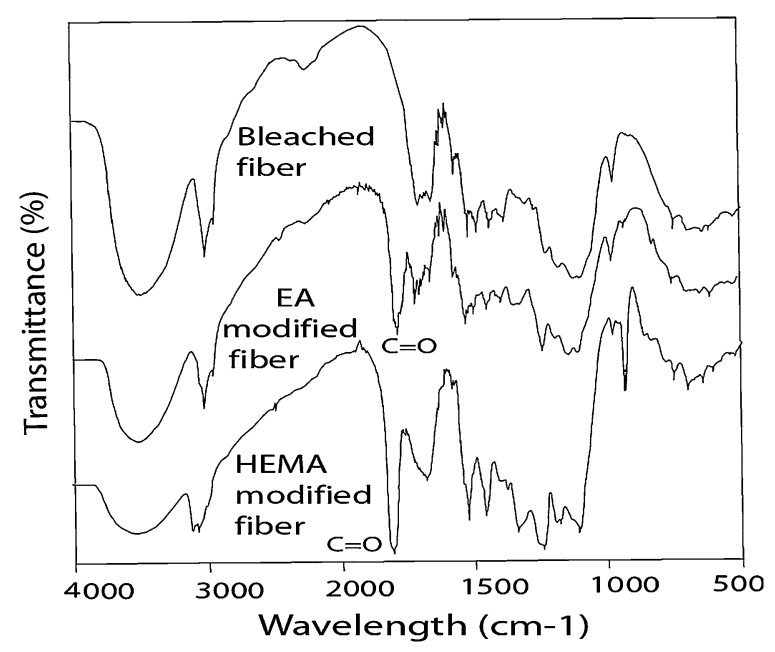

Fig. 2 FT-IR spectra of bleached, EA modified and HEMA modified fibers

1728 and $1718 \mathrm{~cm}^{-1}$ for modified fibers. The additional peaks at 1728 and $1718 \mathrm{~cm}^{-1}$ correspond to the ester carbonyl groups of EA- and HEMA-modified fibers, respectively. The carbonyl peak of HEMA-modified fiber was sharper and more intense, compared to that of EA-modified fiber, due to the higher grafting of HEMA on to the jute macroradicals.

On the IR spectra there are broad absorption spectra in the region of $3300-3600 \mathrm{~cm}^{-1}$ in both EA- and HEMA-modified jute spectra. These can be attributed to the hydroxyl $(\mathrm{OH})$ absorption spectra of primary alcohol of cellulosic units of jute. Due to the presence of extra hydroxyl groups on the monomers, HEMA-modified fiber should have a greater number of $\mathrm{OH}$ groups compared to that of EA-modified fibers. This would cause broader $\mathrm{OH}$ absorption on the HEMA-modified spectra.

However, modified fiber also showed broader $\mathrm{OH}$ absorption. These spectra support the conclusion that some of the $\mathrm{OH}$ groups of HEMA were consumed by the condensation reaction between two grafted HEMA on the jute surface. It is also possible that ssthe $\mathrm{OH}$ group of grafted HEMA and primary alcoholic group of cellulosic units along the fiber length were consumed in condensation reactions. The condensation reaction of $\mathrm{OH}$ groups of two grafted HEMA, and/or OH group of grafted HEMA and OH group of cellulosic units, caused some extent of cross-linking. This cross-linking would significantly contribute to the improvement of thermal and physical properties of HEMAmodified fiber.

\section{Effect of modification on the surface morphology}

The modification of jute fiber with vinyl monomers (EA and HEMA) greatly improved the surface smoothness of the fiber. The improvement of SEM image of modified fiber. From the Fig. 3 it can be seen that the smoothness of jute surface of HEMA-modified fiber is very uniform whereas the surface of unmodified bleached fiber is irregular, ruptured and cracked. The modification tightly bound the irregular and rough surfaces of jute with grafting, or with interpenetrating cross-linking, and finally gave a smooth surface morphology. 

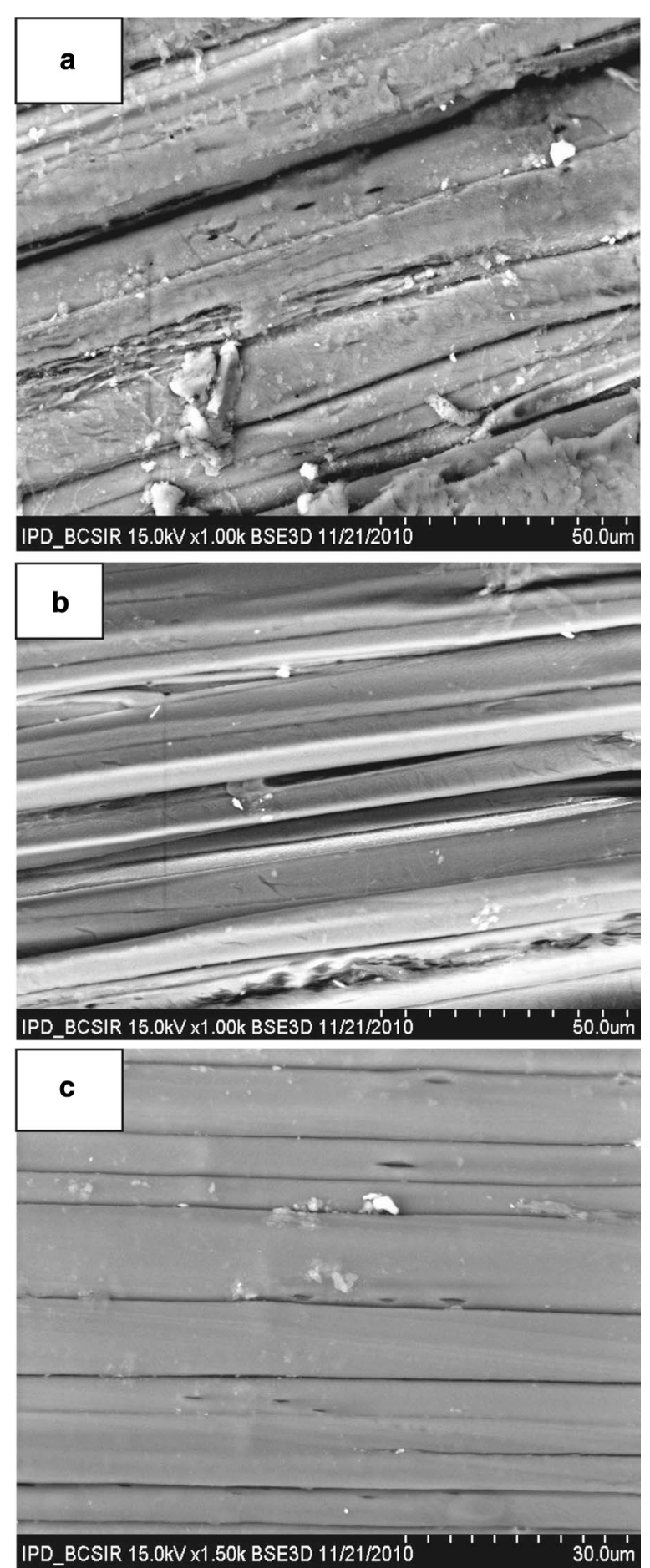

Fig. 3 SEM images of jute fibers: a Bleached fiber, $\mathbf{b}$ EA modified fiber, and $\mathbf{c}$ HEMA modified jute fiber

Breaking strength of sunlight exposed alkali-activated bleached and modified jute fiber From Table 2, it can be seen that the breaking strength of modified jute fiber was higher than that of the alkali-activated bleached fiber. Again, the loss in breaking strength of 
Table 2 Moisture absorption and effect of sunlight on breaking strength of alkali-activated and modified jute fibers

\begin{tabular}{|c|c|c|c|c|}
\hline \multirow[t]{2}{*}{ Type of fiber } & \multirow{2}{*}{$\begin{array}{l}\text { Moisture con- } \\
\text { tent (\%) }\end{array}$} & \multicolumn{3}{|c|}{ Breaking load on sunlight exposure (Kg/Yarn) } \\
\hline & & Exposure period $(0 \mathrm{~h})$ & Exposure period $(250 \mathrm{~h})$ & $\begin{array}{l}\text { Loss of strength } \\
\text { (\%) }\end{array}$ \\
\hline Alkali-activated & 16.6 & 27.5 & 22.2 & 19.0 \\
\hline EA modified & 10.9 & 28.9 & 26.1 & 9.7 \\
\hline HEMA modified & 14.2 & 29.9 & 27.6 & 7.8 \\
\hline
\end{tabular}

grafted fiber on exposure to sunlight in air for $250 \mathrm{~h}$ was approximately $9.7 \%$ for EA, $7.8 \%$ for HEMA, whereas that of for alkali-activated bleached jute was $19 \%$. During grafting, the crystallinity of jute fiber was reduced, due to the incorporation of amorphous co-polymers. At the same time, the swelling of fiber in the grafting medium caused some extent of decrystallization (Haque et al. 1980; Haque and Habibuddowla 1980). The combined effects of incorporation of copolymer and decrystallization phenomena mechanically bound the cellulosic chains, conferring additional strength to the jute fiber.

The incorporation of monomer through grafting provided a protective layer that sufficiently prevented the destructive action of UV rays of sunlight. This ultimately increased the breaking strength as well as decreased the photo-oxidation degradation of the fiber.

The breaking load of HEMA-modified fiber was higher than that of EA-modified fiber. This might be due to higher rigidity of HEMA-jute copolymer than that of EAjute copolymer (Mukhopadhay 1982). Again, as the HEMA formed, some extent of crosslinking between grafted HEMA and/or HEMA-jute macroradicals occurred. This would have contributed additional strength to HEMA-modified fiber.

\section{Moisture content of alkali-activated bleached and modified fiber}

The moisture content of alkali-activated bleached fiber was higher $(16.63 \%)$ than that of modified fibers (EA-modified, $10.9 \%$ and HEMA-modified, $14.2 \%$ ), as shown in Table 2. Due to the modification, the hydrophobic nature of modified fibers increased. This caused the lower moisture absorption by the EA- and HEMA-grafted fibers. Between the EA- and HEMA-modified fibers, the higher absorption of moisture of HEMA-modified fiber is due to the presence of extra $-\mathrm{OH}^{\cdot}$ radicals in the HEMA monomer.

EA and HEMA are hydrophobic monomers, and grafting of these onto jute filled the pith channel of the jute. Grafting with EA and HEMA on the jute fiber might also fill up the capillary spaces present on the surface of and inside the fibers. The monomers may even cover up the fiber surfaces with non-water-absorbable materials. All of this caused reduction of moisture retention and increased hydrophobia of the jute. In the bleached fiber, the pith channel was open. Moisture collected there and was absorbed.

So grafted jute was far more hydrophobic than bleached fiber. This hydrophobia could protect the fiber from water and from microbial attack. The reduction of moisture 
retention is a predictable result, as some hydrophilic groups of hydroxyl reacted with monomers and more hydrophobic chains were introduced to the fiber.

\section{Thermal analysis of alkali-activated bleached and modified jute fibers}

From Fig. 4, it is seen that the weight loss/degradation of the alkali-activated bleached and modified fibers occurred at three steps: around $30-100,250-340{ }^{\circ} \mathrm{C}$ and finally $350-$ $400{ }^{\circ} \mathrm{C}$, respectively. The weight loss at around $30-100{ }^{\circ} \mathrm{C}$ was attributable to the removal of volatile materials and moisture from the fiber, The pyrolysis, starting from 250 to $300{ }^{\circ} \mathrm{C}$, caused the partial breakdown of cellulose backbone and the complete removal of hydrogen from the structure, leaving an impaired carbon skeleton. The degradations in this region were very rapid because of burning of carbon and hydrogen. Another pyrolysis region starting from 350 to $400{ }^{\circ} \mathrm{C}$ gave somewhat slower degradation, with burning of remaining carbon.

Between the unmodified and modified fibers, the later one showed better thermal stability. This may result from the incorporation of acrylate (EA and HEMA) monomers in the fiber surface. The acrylate monomers caused a protective layer to form on to the active surface of the jute fiber. First this layer worked against the applied heat and ultimately decreased the heating impact on the cellulosic backbone. So the modified fiber showed higher thermal stability.

Between the EA- and HEMA-modified fibers, the latter one showed a distinguishablyimproved result. The better thermal performance of HEMA-modified fiber was due to the formation of some cross linking of the intra/inter-cellulosic units with the hydroxyl group of HEMA.

\section{Dyeing exhaustion}

From Table 3, the dye exhaustion percentage of bleached jute fiber was greater than that of grafted fiber. The possible explanation of this difference in dye exhaustion was that dye absorption of a fiber depended on the availability of the total external surface of the fiber pores or cavities in a fixed amount of fiber, and the attractive forces

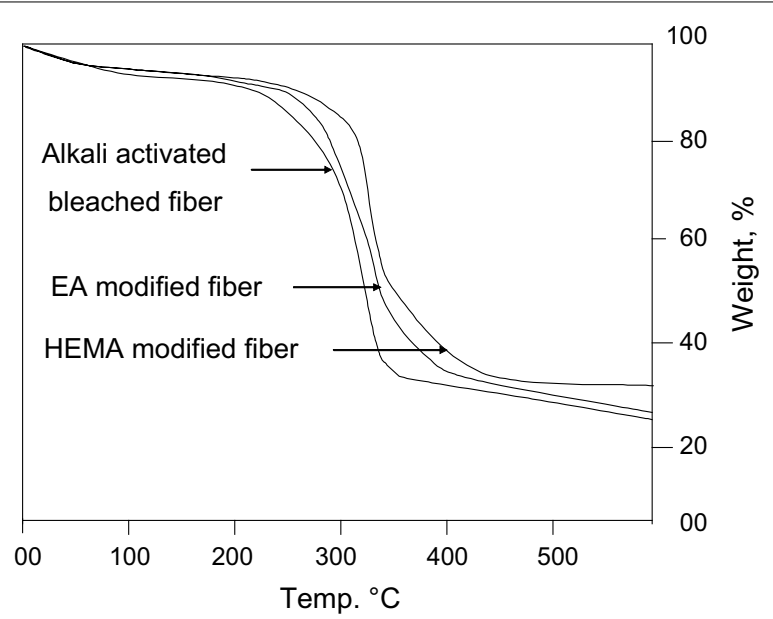

Fig. 4 TGA thermograph of alkali-activated bleached, EA and HEMA modified jute fibers 
Table 3 Dye exhaustion of activated bleached, EA and HEMA modified jute fibers

\begin{tabular}{llll}
\hline Name of dye & \multicolumn{2}{l}{ Dye exhaustion (\%) } & \\
\cline { 2 - 4 } & Alkali-activated bleached fiber & EA-grafted fiber & HEMA-grafted fiber \\
\hline Reactive Orange 14 & 48.7 & 40.2 & 38.9 \\
Reactive Brown 10 & 47.4 & 41.5 & 38.3 \\
Direct Orange 31 & 91.0 & 87.5 & 83.0 \\
Direct Blue 1 & 97.7 & 94.4 & 91.7 \\
\hline
\end{tabular}

between the fiber and dye ions (Mondal and Hoque 2007). The bleached jute fiber had more available pores or cavities than that of the modified jute fiber, which, on grafting, was blocked. Hence, the dye exhaustion of the grafted fiber was less than that of the bleached jute fiber. Again, due to the more hydrophobic nature of the grafted fiber, the dye exhaustion of the grafted fiber was less than that of the alkali-activated bleached jute fiber.

Between the modified fibers, EA-modified fiber showed higher exhaustion of dye than that of HEMA-modified fiber. As the grafting of HEMA was greater than that of EA, the availability of pores or cavities for dye penetration-and so dye absorption-was less for HEMA-modified fiber compared to that of EA modified fiber. Again, the crosslinking of HEMA and jute macroradicals consumed some of the primary hydroxyl groups of jute. This could have somehow reduced the interaction between the dye molecules and jute and ultimately reduced the dye absorption for HEMA modified fiber.

\section{Colorfastness and change in color of dyed jute fibers on sunlight exposure in open air}

The colorfastness of both the bleached and modified (EA and HEMA) jute fibers, dyed with Reactive Orange 14, Reactive Brown 10, Direct Orange 31 and Direct Blue 1 were studied, on exposure to sunlight in open air, by the Grey scale. The result has been shown in Table 4. From Table 4, it can be seen that the colorfastness rating of bleached and modified fibers, after $250 \mathrm{~h}$ exposure to sunlight, was nearly the same. However, the colorfastness of modified fiber was somewhat better than that of bleached fiber. This could be because modification formed a protective layer on the jute surface. This protective layer could have partially protected the jute from UV radiation. This would have decreased the rate of UV-light penetration into the fiber backbone. This effect would decrease the negative effect of the UV-light on the change in colorfastness. Again, that protective layer of modification would reduce the moisture and oxygen diffusion to the sites of fading, resulting in better colorfastness of modified fiber (Khan 2007).

The higher grafting of HEMA, and interpenetrating cross-linking of HEMA on the fiber surface, caused a stronger protective layer than that produced by EA-modified fiber. This stronger protective layer comprehensively reduced the penetration of UV, moisture and oxygen on the sites of fading more effectively than that of EA-modified fiber. As a result, better colorfastness of HEMA-modified fiber was recorded, compared to EA-modified fiber. 


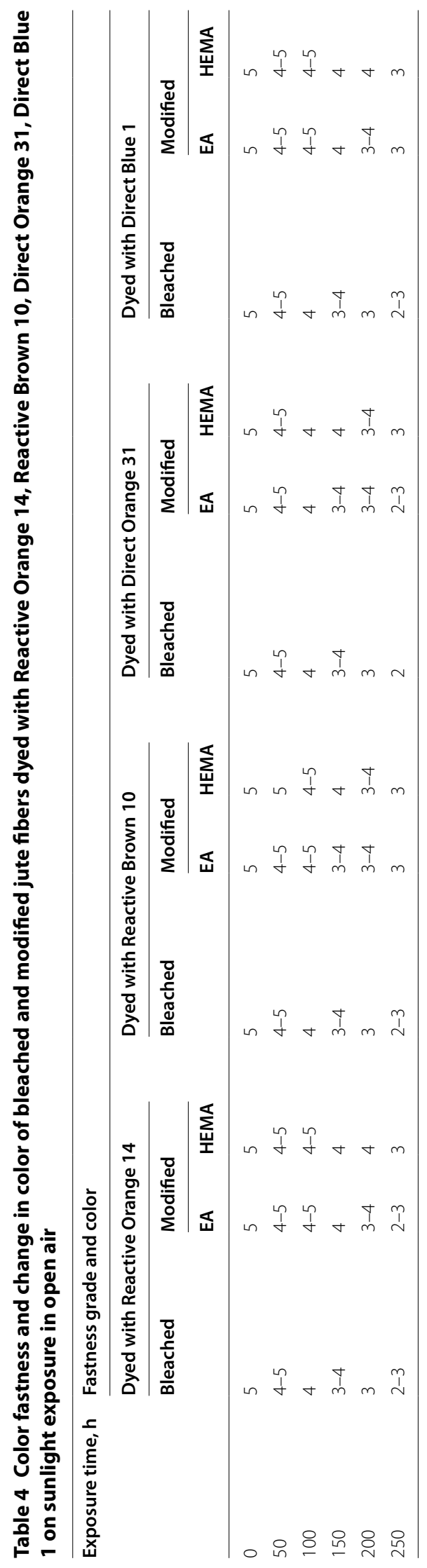




\title{
Conclusions
}

EA and HEMA monomers were grafted to jute macro-radicals by radical polymerization. Prior to modification, alkali activation of bleached jute enhanced the graft yield for both the monomers. Although improved surface morphologies, chemical, thermal and physical properties were found for both monomers, HEMA-modified fiber was better. The grafting decreased the dye-ability of the fiber, and colorfastness in sunlight was improved.

\section{Authors' contributions}

IHM designed the paper, performed the literature survey and completed the paper. MI, MRK, SI and MAR performed the experiments and analyzed the data in consultation with IHM. All authors read and approved the final manuscript.

\author{
Author details \\ ${ }^{1}$ Polymer and Textile Research Lab, Department of Applied Chemistry and Chemical Engineering, Rajshahi University, \\ Rajshahi, Bangladesh. ${ }^{2}$ Department of Apparel Manufacturing Engineering, Bangladesh University of Textiles, Tejgaon, \\ Dhaka 1208, Bangladesh. ${ }^{3}$ BCSIR Laboratories, Rajshahi, Bangladesh.
}

\section{Acknowledgements}

The authors would like to acknowledge the Ministry of Education in Bangladesh for funding the project as Higher Education Research Grant in 2014 (Memo Nos.: 37.01.0000.078.02.018.13-206(38)/6-35, 2014).

\section{Competing interests}

The authors declare that they have no competing interests.

Received: 6 December 2015 Accepted: 7 February 2016

Published online: 24 March 2016

\section{References}

Abou-Zeid, N. Y., Higazy, A., \& Hebeish, A. (1984). Graft copolymerization of styrene, methyl-methacrylate and acrylonitrile onto jute fibers. Die Angewantable Makromolecular Chemie, 121, 69-87.

Chattopadhyay, D. P. (1998). Introduction, chemistry and preparatory processes of jute. Colourage, 5, 23-35.

Farouqui, F. I., \& Mondal, Md. I. H. (1989). Scouring and bleaching of jute fibre in relation to its strength. Rajshahi University Studie Part B-17, 1-8.

Ghosh, P., \& Paul, S. K. (1983). Photo graft copolymerization of methyl methacrylate (MMA) on bleached jute fiber using ferric sulfate $\mathrm{Fe}_{2}\left(\mathrm{SO}_{4}\right)$, as initiator in limited aqueous system. Journal Macromolecular Science and Chemistry, A, 20(2), $169-178$.

Haque, M. M., \& Habibuddowla, Md. (1980). Studies on tenacitities of ceric ion initiated methyl methacrylate grafted jute fibre. Bangladesh Journal of Scientific and Industrial Research, 15(1-4), 64-70.

Haque, M. M., Habibuddowla, Md, Mahmood, A. J., \& Jabber Mian, A. (1980). Graft copolymerization onto jute fiber: Ceric ion-initiated graft copolymerization of methyl methacrylate. Journal of Polymer Science:Polymer Chemistry Edition, 18(5), 1433-1650.

Khan, G. M. (2007). Dyeing of grafted jute fibre with reactive dyes and its improved properties. Thammasat International Journal of Science and Technology, 12(3), 83-87.

Khan, M. A., Majumder, S. C., Rahman, M. A., Noor, F. G., Zaman, H. U., Mollah, M. Z. I., et al. (2010). Mechanical and electrical properties of photocured jute fabric with 2-hydroxy ethylacrylate. Fibers and Polymers, 11(3), 391-397.

Khan, M. A., Rahaman, M. S., Abdullah-Al-Jubayer, \& Islam, J. M. M. (2015). Modification of jute fibers by radiation-induced graft copolymerization and their application (Chapter 11). In Celluluse-based graft copolymers, Thakur, V. K. (Ed), CRC press, Boca Raton, USA, 2015

Misra, M., Mohanty, A. K., \& Singh, B. C. (1987). A study on grafting of methyl methacrylate nto jute fiber $\left(\mathrm{S}^{2} \mathrm{O} 8^{2-}\right.$-thiourea system). Journal of Applied Polymer Science, 33, 2809-2819.

Mondal, Md I H. (2003). Graft copolymerization of nitrile monomers onto sulfonated jute cotton blended fabric. Journal of Applied Polymer Science, 87, 2262-2266.

Mondal, Md I H. (2013). Grafting of Methyl Acrylate and Methyl Methacrylate onto jute fiber: Physico-Chemical characteristics of the grafted jute: Structure and chemistry. Journal of Engineered Fibers and Fabrics, 8(3), 42-50.

Mondal, Md I H, Alam, R., \& Sayeed, Md A. (2004). Graft copolymerization of nitrile monomers onto bleached jute fiber using potassium persulfate system and their textile characteristics. Journal of Applied Polymer Science, 92, 3622-3629.

Mondal, Md I H, Farouqui, F. I., \& Enamul Kabir, F. M. (2002). Graft copolymerization of acrylamide and acrylic acid onto jute fiber using potassium persulfate as initiator. Cellulose Chemistry and Technology, 36, 471-482.

Mondal, Md I H, Farouqui, F. I., \& Salam, M. A. (2006). Graft copolymerization of acrylate monomers onto sulfonated jute cotton blended fabric. Journal of Applied Polymer Science, 100, 4393-4398.

Mondal, Md I H, Farouqui, F. I., Sheikh, R. K., \& Hoque, Md A. (2007). Physico-chemical characteristics of jute fiber grafted with nitrile monomer. Cellulose Chemistry and Technology, 41, 23-28.

Mondal, Md I H, \& Haque, Md M. (2007). Effect of grafting methacrylate monomers onto jute constituents with a potassium persulfate initiator catalyzed by Fe(II). Journal of Applied Polymer Science, 103, 2369-2375. 
Mukhopadhay, A. K., Sarkar, B. K., \& Dutt, A. S. (1982). Effect of grafting on the tensile properties of jute fiber. Journal of Applied Polymer Science, 27, 4525-4527.

Samal, R. K., Dash, S., \& Sahu, A. K. (1990). Graft copolymerization of acrylic acid onto jute fibers initiated by quinquivalent vanadium. Journal of Applied Polymer Science, 41, 195-203.

Sayeed, Md. A., Farouqui, F. I., Islam, Md. N., \& Faruq, M. O. (1987). Dyeing of raw and bleached jute with catechu brown dye. Rajshahi University Studies Part B-15, 1-17.

Sharma, B. R., Kumar, V., \& Soni, P. L. (2003). Graft copolymerization of acrylonitrile onto Cassia tora gum with ceric ammonium nitrate-nitric acid as a redox initiator. Journal of Applied Polymer Science, 90, 129-136.

Sikdar, B., Basak, R. K., \& Mitra, C. (1995). Studies on graft copolymerization of acrylonitrile onto jute fiber with permanganate ion initiation system in presence of air. Journal of Applied Polymer Science, 55, 1673-1682.

Tanmoy, A. M., Alum, M. A., Islam, M. S., Farzana, T., \& Khan, H. (2014). Jute (Corchorus olitorius var. o-72) stem lignin: variation in content with age. Bangladesh Journal of Botany, 43(3), 309-314.

Zaman, H. U., Khan, M. A., \& Khan, R. A. (2012). Effect of gamma radiation and bulk monomer on jute fabrics polyethylene/ polyvinyl chloride composites. Journal of Polymer Engineering, 32(4-5), 301-309.

\section{Submit your manuscript to a SpringerOpen ${ }^{\circ}$ journal and benefit from:}

- Convenient online submission

- Rigorous peer review

- Immediate publication on acceptance

- Open access: articles freely available online

- High visibility within the field

- Retaining the copyright to your article

Submit your next manuscript at $\mathbf{s p r i n g e r o p e n . c o m ~}$ 